Пылайкина Вера Петровна канд. филол. наук, доцент ФГБОУ ВО «Уральский государственный педагогический университет» г. Екатеринбург, Свердловская область

DOI $10.21661 / r-117043$

\title{
MARITAL TERMS AND LINGUACULTURAL GENDER
}

Аннотация: грамматическая категория рода превратилась в лингвосоциокультурную в современном аналийском языке. Семантический анализ существительных, которые закреплены за лицами определённого пола, выявляет отношение общества к людям. В современном английском языке представители обоих полов оцениваются отрицательно. В результате семантического анализа терминов родства выявлены новые тенденции в обществе, гендерные асимметрии, сопутствующие коннотациии.

Ключевые слова: грамматический род, биологический пол, сочииальные роли, отношение общества, пейоративная оценка, негативные коннотации.

Abstract: grammatical category of old English nouns has transformed into a linguacultural category in modern English. Semantic analysis of the lexical meaning of nouns denoting human beings reveals the covert attitude of society to them. In modern English the attitude is mostly negative to both men and women. Semantic analysis of terms denoting fathers and mothers reveal new trends in the society, gender asymmetries, connotations and hidden implications.

Keywords: grammatical gender, biological sex, social roles, attitude of society, pejorative meaning, negative connotations.

It is a scientific fact that modern English noun has no grammatical category of gender. At the same time, there are words that are used to name only men (boy, man, sister) or women (girl, woman, brother). Gender language studies that began last century provide an opportunity to classify these numerous words into a category. This category has little to do with the real biological sex of human beings. It reflects mainly 
the social roles that people have to play. We provided evidence in our research paper that former grammatical category of gender has gradually transformed into a linguacultural category. It falls into three main groups: nouns of dual gender (lawyer, doctor), words with feminine suffixes (actress, heroine), feminine or masculine nouns in accordance with their lexical meaning (alpha male, femme fatal). It was revealed that gender distinctions in modern English serve to express an attitude of society to men and women. This attitude turned out to be mostly negative [1].

One of the semantic groups that reflects various social roles of people is linked with their marital status. Words denoting a father and a mother are of Anglo-Saxon origin. They have been in the stock of the English vocabulary since Old English - foeder (masculine), modor (feminine). The analysis of family terms helps to trace some changes in the life of modern society. Many European countries encounter the problem of teenage pregnancies. There appeared a term "gymslip mother' which denotes a girl of school age, who gave birth to a child (gymslip is a part of schoolgirl uniform). Mothers in their teens are often viewed as a family or even national disgrace. Though the word is neutral the implications are negative. A surrogate mother agrees to give birth to a child on behalf of another woman, who is unable to do that herself.

Family relations and matrimony is a sphere of life in which women dominate. The status of a married woman is much higher than that of a single woman. The nouns «spinster' and «old maid' are disparaging and offensive and are perceived as insulting. The implications are that women of this kind are fussy, unable to find a husband being advanced in age. «Bachelorette' was coined in 1935 from «bachelor' but was not actively used. Now it is labelled as humorous and denotes a young unmarried professional woman. It is often used in a combination «bachelorette party» in the meaning of «hen party' or «hen night' (a party for a woman who is getting married to which only women are invited).

«Bridezilla' is a blend of a «bride’ and «Godzilla' (a monster in Japanese horror films). A woman is so obsessed with her own coming wedding ceremony that she becomes a real monster. She terrorizes family members and friends, because this is the 
most important day in her life and it should be perfect. She becomes intolerable and the connotations are strongly negative.

Women are traditionally treated as objects. This is a long-established gender metaphor. A «trophy wife' denotes a young attractive woman who is married to an older man and thought of as a trophy, which shows that this man is successful. Her main duty is to impress other people. Online Collins English Dictionary labels the word as pejorative.

The relations between mothers and work have always been strained. «Full-time mothers' devote themselves wholly to children, family and their home. Some women try hard to combine both family and work: mumpreneur, supermom, WHAM (work at home mum). Many women find the terms offensive, because they minimise their achievement, centre on their activities as mothers, not as professionals. «Superdad' reveals gender asymmetry. He either shouts profanities at baseball games or watch from a distance little girls playing in the sand. A not so often used noun «returner' denotes mainly a woman who returns to her working place after having children. It is difficult for mothers to find a job, to be promoted, to get a higher salary. They are stopped by a «maternal wall' or have to follow a «mommy track'.

Parents in the $21^{\text {st }}$ century are overprotective of their children. A whole collection of terms proves the statement. The idea of parents who are over-anxious about their responsibilities is not new. The term «helicopter parent' was first used in 1969 but it became a dictionary entry only in 2011. The term is mainly associated with parents of high-school or college students. They would call colleges and arrange meetings with teachers, discuss schedules, grades, training exercises, etc. Similar terms are «hover(ing) parents', «blackhawk parents', «curling parents', «lawnmower parenting', «cosseting parent', «bulldoze parenting'. There are correlating pairs of nouns: hover/helicopter mother and hover/helicopter father. Behavioral gender differences between them are uncovered and described. Mothers dominate and manipulate all spheres of life of their kids but they are more subtle and help behind the scene. Fathers are not interested in details. They are straightforward, go to authorities with requests 
and even threats. The effect on children varies from low self-esteem and underdeveloped life skills to the sense of entitlement. Celebrities take management of their children in their own hands and become «stage parents'. The nouns "stage father' and «stage mother' were coined. Stage mother can become a «momager' (mom + manager) and is more aggressive in her attempts to advance a child's career.

«Soccer mom' is an American term for a caring parent. It was coined to denote a mother who lives in the suburbs and is driving her children to some sports activity (soccer practice) after school. She should drive a minivan or an SUV. In Canada and Northern states of the USA the word «hockey mom' is used as mothers take their children to hockey rinks. «Soccer dad' reveals gender asymmetry as he allows his children everything soccer mom forbids - TV and the Internet, swearing, etc.

The lexical meaning of «soccer mom» has changed considerably. It developed in two ways. The first trend is linked with American politics. Soccer moms represented a voting demographic and were targeted as a potential swing group in electoral campaigns of several politicians. The noun is loaded with senses; no woman would like to be called like that. It began to mean a family-focused, middle-class woman, occasionally used as a demographic. She is now mainly a coveted consumer and is a target for advertisers. Politicians relied on «security moms", who were concerned with the war in Iraq, domestic terrorism and security of their children. Alaska governor and candidate for vice president Sarah Palin coined and successfully employed «mama grizzly' metaphor. The plural form was used later about female candidates whom she supported in the 2010 electoral campaign.

Several correlating masculine nouns were created to match the term «soccer mom' in this political sense: «NASCAR dad' (working class, high school-educated father with no political affiliation) and «office park dad' (a married, suburban-living father, who has a white-collar job). Both groups were seen as an important political demographic for the electoral campaigns. 
Another development of «soccer mom' has nothing to do with politics. «Tiger mom' is pushy, drives her children very hard to succeed at school and in extra-curricular activities. The term became popular in 2011 when Amy Chua, a Yale professor of law, published her book «Battle Hymn of the Tiger Mother».

Inept parents are also stigmatized. «Deadbeat dads' and moms neglect their duties. It should be noted that the term is more often used with masculine gender nouns. Fathers are not responsible; do not provide financial support for their children. In addition to this definition «deadbeat husbands' mentally abuse their wives and act as authorities in the household. «Sunday dads' choose to communicate with their children on Sundays. Fathers fail their duties.

Women's appearance cannot be left unnoticed. «Yummy mummy' denotes an attractive mother. Food metaphor is often used with feminine nouns. Many women think it is offensive.

The analysis of marital and family terms proves that they hide a covert attitude of society to its members. Parents of either sex are overprotective of their children. Mothers can be more aggressive and persistent in carrying out their duties. Fathers can neglect their duties. Both are a target for American politicians in their electoral campaigns, though feminine terms were coined first, are more numerous and have more implications and connotations. Additionally mothers are viewed by advertisers as potential consumers of a wide variety of goods. Gender asymmetries are found in this group of terms. Food and instrumental metaphors are used about women. Many feminine nouns are perceived as humorous, pejorative or even offensive.

\section{Список литературы}

1. Пылайкина В.П. Категория гендера в английском языке в сопоставлении с русским: Дис. ... канд. филол. наук / В.П. Пылайкина; Уральский гос. пед. ун-т. - Екатеринбург, 2004. - 187 с.

2. Collins English Dictionary [Электронный pecypc]. - Режим доступа: http: // www.collinsdictionary.com (дата обращения: 29.12.2016).

3. Your Dictionary [Электронный pecypc]. - Режим доступа: http://www.yourdictionary.com (дата обращения: 29.12.2016). 